\title{
Front Matter: Volume 7763
}

, "Front Matter: Volume 7763," Proc. SPIE 7763, Terahertz Emitters, Receivers, and Applications, 776301 (28 September 2010); doi: 10.1117/12.878484

SPIE Event: SPIE NanoScience + Engineering, 2010, San Diego, California, United SPIE. States 


\section{PROCEEDINGS OF SPIE}

\section{Terahertz Emitters, Receivers, and Applications}

Jean-François Lampin

Didier J. Decoster

Manijeh Razeghi

Editors

1 and 3 August 2010

San Diego, California, United States

Sponsored and Published by

SPIE

Volume 7763

Proceedings of SPIE, 0277-786X, v. 7763 
The papers included in this volume were part of the technical conference cited on the cover and title page. Papers were selected and subject to review by the editors and conference program committee. Some conference presentations may not be available for publication. The papers published in these proceedings reflect the work and thoughts of the authors and are published herein as submitted. The publisher is not responsible for the validity of the information or for any outcomes resulting from reliance thereon.

Please use the following format to cite material from this book:

Author(s), "Title of Paper," in Terahertz Emitters, Receivers, and Applications, edited by Jean-François Lampin, Didier J. Decoster, Manijeh Razeghi, Proceedings of SPIE Vol. 7763 (SPIE, Bellingham, WA, 2010) Article CID Number.

ISSN 0277-786X

ISBN 9780819482594

Published by

SPIE

P.O. Box 10, Bellingham, Washington 98227-0010 USA

Telephone +1 3606763290 (Pacific Time) · Fax +1 3606471445

SPIE.org

Copyright (C) 2010, Society of Photo-Optical Instrumentation Engineers

Copying of material in this book for internal or personal use, or for the internal or personal use of specific clients, beyond the fair use provisions granted by the U.S. Copyright Law is authorized by SPIE subject to payment of copying fees. The Transactional Reporting Service base fee for this volume is $\$ 18.00$ per article (or portion thereof), which should be paid directly to the Copyright Clearance Center (CCC), 222 Rosewood Drive, Danvers, MA 01923. Payment may also be made electronically through CCC Online at copyright.com. Other copying for republication, resale, advertising or promotion, or any form of systematic or multiple reproduction of any material in this book is prohibited except with permission in writing from the publisher. The CCC fee code is 0277-786X/10/\$18.00.

Printed in the United States of America.

Publication of record for individual papers is online in the SPIE Digital Library.

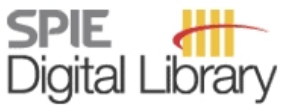

SPIEDigitalLibrary.org

Paper Numbering: Proceedings of SPIE follow an e-First publication model, with papers published first online and then in print and on CD-ROM. Papers are published as they are submitted and meet publication criteria. A unique, consistent, permanent citation identifier (CID) number is assigned to each article at the time of the first publication. Utilization of CIDs allows articles to be fully citable as soon they are published online, and connects the same identifier to all online, print, and electronic versions of the publication. SPIE uses a six-digit CID article numbering system in which:

- The first four digits correspond to the SPIE volume number.

- The last two digits indicate publication order within the volume using a Base 36 numbering system employing both numerals and letters. These two-number sets start with 00, 01, 02, 03, 04, $05,06,07,08,09,0 A, 0 B \ldots 0 Z$, followed by 10-1Z, 20-2Z, etc.

The CID number appears on each page of the manuscript. The complete citation is used on the first page, and an abbreviated version on subsequent pages. Numbers in the index correspond to the last two digits of the six-digit CID number. 


\section{Contents}

$\checkmark$ Conference Committee

\section{SESSION 1 QUANTUM CASCADE LASERS}

776303 Microdisk THz quantum-cascade lasers with super-conducting cavities [7763-02]

A. Benz, M. Brandstetter, C. Deutsch, G. Fasching, A. M. Andrews, P. Klang, W. Schrenk,

G. Strasser, K. Unterrainer, Technische Univ. Wien (Austria)

776304 THz QCL-based active imaging dedicated to Non-Destructive Testing of composite materials used in aeronautics [7763-03]

F. Destic, Y. Petitjean, S. Massenot, ISAE, Univ. de Toulouse (France); J.-C. Mollier, ISAE, Univ. de Toulouse (France) and ONERA (France); S. Barbieri, Univ. Paris-Diderot (France)

776305 Surface-emitting terahertz quantum cascade ring lasers [7763-04]

C. Deutsch, E. Mujagić, A. Benz, A. M. Andrews, P. Klang, H. Detz, W. Schrenk, G. Strasser,

K. Unterrainer, Technische Univ. Wien (Austria)

776306 Direct modulation and bandwitdh measurement of terahertz quantum cascade laser [7763-05]

Y. Petitjean, F. Destic, Institut Supérieur de l'Aéronautique et de l'Espace (France); S. Barbieri,

C. Sirtori, Univ. Paris 7-Denis Diderot (France); J.-C. Mollier, Institut Supérieur de

l'Aéronautique et de l'Espace (France) and ONERA (France)

\section{SESSION 2 OTHER SOURCES AND DETECTORS}

776307 Photonic generation of continuous terahertz waves and its application to sensing and communications (Invited Paper) [7763-06]

H.-J. Song, N. Shimizu, Y. Kado, NTT Microsystem Integration Labs. (Japan); T. Nagatsuma, Osaka Univ. (Japan)

776308 Detectors of terahertz radiation based on $\mathrm{Pb}_{1-\mathrm{x}} \mathrm{Sn} \times \mathrm{Te}(\mathrm{In})$ [7763-07]

D. Khokhlov, Lomonosov Moscow State Univ. (Russian Federation)

776309 Optically-electrically pumped THz source [7763-08]

B. Haji-Saeed, J. Khoury, W. Buchwald, C. Woods, Air Force Research Lab. (United States);

S. Wentzell, B. Krejca, J. Kierstead, Solid State Scientific Corp. (United States)

7763 OA High efficiency optoelectronic terahertz sources [7763-09]

J.-F. Lampin, E. Peytavit, T. Akalin, G. Ducournau, Institut d'Electronique, de Microélectronique et de Nanotechnologie, CNRS, Univ. de Lille 1 (France); F. Hindle, G. Mouret, Lab. de Physico-Chimie de l'Atmosphère, CNRS, Univ. du Littoral Côte d'Opale (France) 
7763 OB Terahertz nonlinear spectroscopy of free-carriers in direct bandgap semiconductors (Invited Paper) [7763-11]

L. Razzari, INRS-EMT. Univ. du Québec (Canada) and Univ. di Pavia (Italy); F. Blanchard, INRS-EMT. Univ. du Québec (Canada); F. H. Su, Univ. of Alberta (Canada); G. Sharma, INRS-EMT. Univ. du Québec (Canada); A. Ayesheshim, T. L. Cocker, L. V. Titova, Univ. of Alberta (Canada); H.-C. Bandulet, R. Morandotti, J.-C. Kieffer, T. Ozaki, INRS-EMT. Univ. du Québec (Canada); M. Reid, Univ. of Northern British Columbia (Canada); F. A. Hegmann, Univ. of Alberta (Canada)

7763 OC Frequency metrology of a photomixing source for gas phase spectroscopy [7763-12] F. Hindle, G. Mouret, C. Yang, A. Cuisset, R. Bocquet, Lab. de Physico-Chimie de I'Atmosphère, CNRS, Univ. du Littoral Côte d'Opale (France); M. Lours, D. Rovera, Observatoire de Paris, CNRS (France)

7763 OD Molecular-level engineering of THz/IR-sensitive materials for future biological sensing application (Keynote Paper) [7763-17]

D. Woolard, Army Research Office (United States) and North Carolina State Univ. (United States); G. Recine, Fordham Univ. (United States) and North Carolina State Univ. (United States); A. Bykhovski, W. Zhang, North Carolina State Univ. (United States)

\section{POSTER SESSION}

7763 OG A tunable terahertz photodetector based on electrical confinement [7763-16] W. Wu, H. Mohseni, Northwestern Univ. (United States)

Author Index 


\title{
Conference Committee
}

\author{
Symposium Chairs
}

David L. Andrews, University of East Anglia Norwich (United Kingdom)

James G. Grote, Air Force Research Laboratory (United States)

\section{Conference Chairs}

Jean-François Lampin, Institut d'Electronique, de Microélectronique, et de Nanotechnologie (France)

Didier J. Decoster, Université Lille 1 (France)

Manijeh Razeghi, Northwestern University (United States)

Program Committee

Jean-Louis Coutaz, Université de Savoie (France)

Alexander Giles Davies, University of Leeds (United Kingdom)

Daniel Dolfi, Thales Research \& Technology (France)

Alexander Luis Gaeta, Cornell University (United States)

Qing Hu, Massachusetts Institute of Technology (United States)

Heinz-Wilhelm Hübers, Deutsches Zentrum für Luft- und Raumfahrt e.V. (Germany)

Peter Uhd Jepsen, Den Polytekniske Laereanstalt Danmarks Tekniske Universitet (Denmark)

Arttu R. Luukanen, VTT Technical Research Center of Finland (Finland)

Gael Mouret, Université du Littoral Côte d'Opale (France)

Gregory S. Nusinovich, University of Maryland, College Park (United

States)

Michele Ortolani, Istituto di Fotonica e Nanotecnologie (Italy)

Staffan Rudner, Chalmers University of Technology (Sweden)

Peter H. Siegel, California Institute of Technology (United States)

Carlo Sirtori, Université Paris Diderot (France)

Andreas Stohr, Universität Duisburg-Essen (Germany)

John M. Zavada, Army Research Office (United States)

Session Chairs

1 Quantum Cascade Lasers

Didier J. Decoster, Université Lille 1 (France) 
2 Other Sources and Detectors

Jean-Francois Lampin, Institut d'Electronique, de Microélectronique, et de Nanotechnologie (France)

3 Imagery and Other Applications

Manijeh Razeghi, Northwestern University (United States) 